Ann. Biol. anim. Bioch. Biophys., 1978, 18 (2 B), 461-470.

\title{
Production of fertilizable oocytes from follicles of rainbow trout (Salmo gairdnerii) following in vitro maturation and ovulation
}

\author{
by B. JALABERT * \\ with the technical assistance of Marie-Claire THERON and Micheline HEYDORFF. \\ Laboratoire de Physiologie des Poissons, I. N. R. A. \\ 78350 jouy en Josas, France.
}

Summary. Trout ovarian follicles were taken in vivo with oocytes showing a peripheral germinal vesicle (fig. 1 : stage $1^{\circ}$, before natural induction of maturation) and incubated at $10^{\circ} \mathrm{C}$ with hormones to complete maturation. PGF $F_{2 \alpha}$ was added after 6,7 or 8 days of incubation and ovulations were recorded 24 hours later. By this means, trout pituitary extract, pure trout gonadotropin t-GtH, or $17 \alpha$-hydroxy-20 $\beta$-dihydro-progesterone $(17 \alpha-$ $20 \beta$ P) was equally effective for production of fertilizable oocytes after $7+1$ days of incubation. After only 6-day maturation incubation, $\mathrm{PGF}_{2 \alpha}$ was already able to induce successful ovulation, but fertilizability was near zero ; after 8-day maturation incubation, responsiveness to $\mathrm{PGF}_{2 \alpha}$ was lost (tables $1,2,3$ ). The dose of $17 \alpha-20 \beta \mathrm{P}$ required for further successful ovulation response to $\mathrm{PGF}_{2 \alpha}$ was more than 10 times higher than required for GVBD completion only (fig. 2), and a 24-hour exposure of follicles to $17 \alpha-20 \beta$ P action at the beginning of incubation was more efficient than a 4-hour exposure or continuous exposure (table 4).

When follicles with oocytes already engaged in the process of maturation in vivo (incubation started at any time between stage $1^{+}$and GVBD) were transferred in vifro, addition of t-GtH or $17 \alpha-20 \beta$ P enhanced further ovulation response to $\mathrm{PGF}_{2 \alpha}$.

These facts show that $17 \alpha-20 \beta \mathrm{P}$, the most likely mediator of oocyte maturation in trout, is also able to induce follicle preparation to ovulation. But this preparation to ovulation needs higher doses and longer exposure to $17 \alpha-20 \beta$ P action than oocyte maturation induction does; this also implies longer exposure to high doses of $\mathrm{t}-\mathrm{G}+\mathrm{H}$ in vivo.

Fertilization of eggs produced in the above conditions shows that in vitro maturation and ovulation must be very similar to the natural processes in vivo.

In rainbow trout, intrafollicular maturation (resumption of meiosis) of oocyte with a peripheral germinal vesicle (PGV) can be triggered in vitro by fish pituitary extracts and some steroids (Jalabert, Breton and Bry, 1972 ; Jalabert ef al., 1973). This response was used as a bioassay for fish gonadotropin (Jalabert, Breton and Billard, 1974) and allowed purification of a specific gonadotropin, t-GtH (Breton, Jalabert and Reinaud, 1976). Among steroids, $17 \alpha$ hydroxy-20 $\beta$ dihydroxyprogesterone (4 pregnen-17 $\alpha, 20 \beta$ diol-3 one ; Abr. $17 \alpha-20 \beta$ P) was shown to be the most potent steroid-inducer of trout oocyte maturation (Fostier, Jalabert and Terqui, 1973) and

* Present address : Laboratoire de Physiologie des Poissons, I. N. R. A. Université de RennesBaulieu, Bât. A-1er cycle, avenue du Général-Leclerc, B. P. 25 A, 35301 Rennes Cedex, France. 
appeared as the most likely mediator produced by the follicular envelopes in response to t-GtH action (Jalabert, 1976).

On the other hand, ovulation (active expulsion of oocyte from the mature follicle) of trout follicles matured in vivo can be induced in vitro by PGF $_{2 \alpha}$ (Jalabert and Szöllösi, 1975). But in the non-sterile incubation conditions employed so far, sufficient at $10^{\circ} \mathrm{C}$ or $15{ }^{\circ} \mathrm{C}$ for studying maturation of the oocyte protected by follicular envelopes and the chorion, ovulation could not be triggered af the end of in vitro maturation, probably because of alteration of the functional integrity of follicular envelopes. On the contrary, Sakun and Gureeva-Preobrazhenskaya (1975) claim to have observed spontaneous ovulation in vitro in rainbow trout following simple treatment by pink salmon pituitary extract or progesterone.

The present work using long-term sterile incubation techniques was aimed at production of fertile eggs from follicles successively induced to mature and to ovulate by pure hormones in order to :

1) show that the process termed until now as maturation, is normal and non-abortive ;

2) understand the modification of hormone action so that ovulation can follow in vitro maturation ;

3) try to clarify the apparent contradictions between our data and observations by Sakun and Gureeva-Preobrazhenskaya (1975).

\section{Materials and methods.}

Ovaries were removed from 2-3 year old rainbow trout (Salmo gairdnerii) during the normal spawning season from November to February. Females were chosen according to the state of maturity of a few oocytes squeezed out by abdominal stripping. The different maturation stages selected for the experiments are schematically shown

(1)

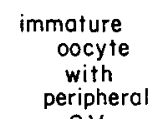

G.V.
(2)

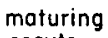

oocyte

before

G.V.B.D
(3)

$\begin{array}{cc}\begin{array}{c}\text { maturing } \\ \text { ocyte ofter }\end{array} & \begin{array}{c}\text { mature oocyte } \\ \text { ofter follicle } \\ \text { G.V.B.D }\end{array} \\ \text { detochment }\end{array}$

ovulation

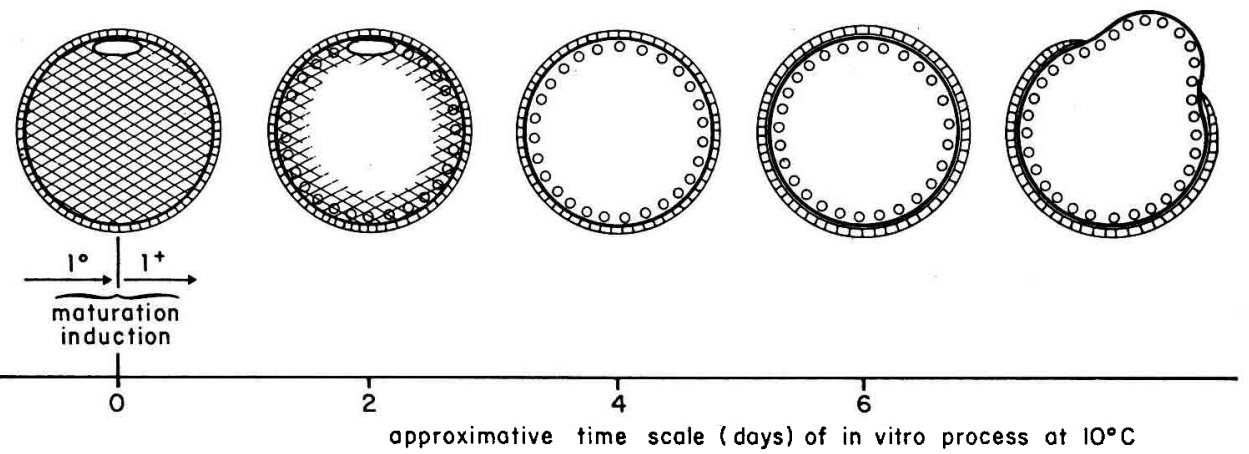

FIG. 1. - Schematic representation of the different stages of oocyte maturation as function of time at $10^{\circ} \mathrm{C}$ in vitro. G. V. : germinal vesicle ; GVBD : Germinal Vesicle Breakdown. 
on figure 1. Stage 1 (peripheral germinal vesicle, opaque yolk) has been subdivided into two parts which can be distinguished only a posteriori from the evolution of control follicles during incubation : follicles at stage $1^{0}$ never mature in vitro without hormone addition; follicles at stage $1^{+}$are able to complete germinal vesicle breakdown (GVBD) in vitro without hormone and are supposed to be taken just after in vivo natural gonadotropic induction of maturation but before any morphological change becomes obvious in yolk structure.

Incubations were carried out at $10{ }^{\circ} \mathrm{C}$ under an atmosphere of 1 p. $100 \mathrm{CO}_{2}-$ 49 p. $100 \mathrm{O}_{2}-50$ p. $100 \mathrm{~N}_{2}$ in Trout balanced solution (TBSS) buffered around pH 8 with $\mathrm{NaHCO}_{3}\left(\mathrm{NaCl} 7.51 \mathrm{~g} / 1 ; \mathrm{KCl} 0.23 \mathrm{~g} / \mathrm{l} ; \mathrm{MgSO}_{4}\left(7 \mathrm{H}_{2} \mathrm{O}\right) 0.07 \mathrm{~g} / \mathrm{l} ; \mathrm{MgCl}_{2}\left(6 \mathrm{H}_{2} \mathrm{O}\right)\right.$ $0.20 \mathrm{~g} / \mathrm{l} ; \mathrm{CaCl}_{2} 0.50 \mathrm{~g} / \mathrm{l} ; \mathrm{NaHCO}_{3} 2.055 \mathrm{~g} / \mathrm{l} ;$ glucose $\left.1 \mathrm{~g}\right)$.

Trout pituitary extract (TPE) and purified trout gonadotropin ( $t-G+H)$ were prepared according to Breton, Jalabert and Reinaud (1976). 4 Pregnen-17 $\alpha, 20 \beta$ diol-3 one $(17 \alpha-20 \beta P)$ was prepared from $17 \alpha$ hydroxyprogesterone and purified as described in Jalabert et al. (1977). Those hormones were added in TBSS at the beginning of incubation at doses known to induce 100 p. 100 maturation (TPE : $\left.5.10^{3} \mathrm{ng} / \mathrm{ml} ; \mathrm{t}-\mathrm{GHH}: 3.10^{2} \mathrm{ng} / \mathrm{ml} ; 17 \alpha-20 \beta \mathrm{P}: 3.10^{-6} \mathrm{M}\right)$ unless otherwise mentioned in fig. and tables.

The ability of follicles to ovulate was checked at the end of incubation $24 \mathrm{hrs}$ after addition of prostaglandin $F_{2 \alpha}\left(P F_{2 \alpha}: 10^{-5} \mathrm{M}\right.$ ) from the Upjohn Co. (Kalamazoo, Michigan).

After artificial insemination with diluted sperm (1/100) according to the technique described by Billard et al. (1974), fertilizability of ovulated oocytes was quantified from the proportion of eggs with normal embryo after 10 days of development.

TABLE 1

Incubotion for $7+1$ days from stage $1^{\circ}$ (germinal vesicle peripheral)

\begin{tabular}{|c|c|c|c|c|c|}
\hline \multirow[b]{2}{*}{$\begin{array}{l}\text { Female } \\
\text { Nr. }\end{array}$} & \multirow[b]{2}{*}{$\begin{array}{l}\text { Number of } \\
\text { follicles }\end{array}$} & \multicolumn{3}{|c|}{ Incubation for maturation (7 days) } & \multirow{2}{*}{$\begin{array}{l}\text { p. } 100 \text { ovulation } \\
1 \text { day after } \\
\text { addition of } \mathrm{PGF}_{2^{\alpha}}\end{array}$} \\
\hline & & Treatment & $\begin{array}{c}\text { P. } 100 \\
\text { degenerating } \\
\text { oocytes }\end{array}$ & $\begin{array}{c}\text { p. } 100 \\
\text { maturation }\end{array}$ & \\
\hline 50 & $\begin{array}{l}196 \\
194 \\
197 \\
175\end{array}$ & $\begin{array}{c}\text { Control } \\
\text { TPE } \\
t-G+H \\
17 \alpha-20 \beta P\end{array}$ & $\begin{array}{c}25,0 \text { ** } \\
7,7 \\
6,6 \\
6,9\end{array}$ & $\begin{array}{c}0 \\
92,3 \\
93,4 \\
93,1\end{array}$ & $\begin{array}{c}0 \\
31,3 \\
37,0 \\
10,4\end{array}$ \\
\hline 51 & $\begin{array}{l}200 \\
198 \\
190 \\
170\end{array}$ & $\begin{array}{c}\text { Control } \\
\text { TPE } \\
t-G+H \\
17 \alpha-20 \beta P\end{array}$ & $\begin{array}{c}10,5 \\
1,5 * \\
7,9 \\
7,1\end{array}$ & $\begin{array}{c}0 \\
98,5 \\
92,1 \\
92,9\end{array}$ & $\begin{array}{c}0 \\
39,0 \\
33,7 \\
43,7\end{array}$ \\
\hline 46 & $\begin{array}{l}168 \\
166 \\
168\end{array}$ & $\begin{array}{c}\text { Control } \\
t-G t H \\
17 \alpha-20 \beta P\end{array}$ & $\begin{array}{l}10,7 \\
16,3 \\
3,0 \text { ** }\end{array}$ & $\begin{array}{c}0 \\
83,9 \\
97,0\end{array}$ & $\begin{array}{c}0 \\
6,5 \\
92,6\end{array}$ \\
\hline 47 & $\begin{array}{l}203 \\
204\end{array}$ & $\begin{array}{c}\text { Control } \\
17 \alpha-20 \beta P\end{array}$ & $\begin{array}{c}24,6 \\
9,8 * *\end{array}$ & $\begin{array}{c}0 \\
90,2\end{array}$ & $\begin{array}{c}0 \\
61,4\end{array}$ \\
\hline
\end{tabular}


Statistical analysis of results calculated as per cent of response $(p)$ in the same number of follicles (usually 200) was carried out by analysis of variance after transformation are $\sin \sqrt{\frac{P}{100}}$.

\title{
Results.
}

Maturation and ovulation responses of follicles from 4 different females incubated in vitro from stage $1^{\circ}$ are shown on table 1 . Control follicles without hormones never matured or ovulated, but exhibited a proportion of degenerating oocytes significantly higher than hormone-treated groups in which all other oocytes matured. Either TPE t-GtH or $17 \alpha-20 \beta P$ seems to be able to prepare for a positive ovulatory response to PGF $_{2 \alpha}$; while some differences appear in the relative efficiency of the different treatments in individual females, no overall tendency is found.

\section{TABLE 2}

\begin{abstract}
Mean p. 100 of ovulation observed 1 day after addition of $P G F_{2^{\alpha}}$ following incubation with hormones for 6, 7 or 8 days (control follicles never mature or ovulate).

The number of females and the number of follicles per female from which mean ovulation percentage is calculafed are shown in brackets
\end{abstract}

\begin{tabular}{|c|c|c|c|}
\hline \multirow{2}{*}{ Hormonal treatment } & \multicolumn{3}{|c|}{$\begin{array}{l}\text { Duration of incubation prior to addition } \\
\text { of } P G F_{2 \alpha}\end{array}$} \\
\hline & 6 & 7 & 8 \\
\hline Trout pituitary extract.. & No assay & $\begin{array}{l}33,6 \\
(2 \times 200)\end{array}$ & No assay \\
\hline t-GtH $\ldots \ldots \ldots$ & $\begin{array}{l}10,0 \\
(2 y, 200)\end{array}$ & $\begin{array}{l}24,6 \\
(3 \times 200)\end{array}$ & $\begin{array}{c}4,8 \\
(2 \times 200)\end{array}$ \\
\hline $17 \alpha-20 \beta P$ & $\begin{array}{l}45,8 \\
(3 \times 200)\end{array}$ & $\begin{array}{c}48,8 \\
(4 \times .200)\end{array}$ & $\begin{array}{c}3,8 \\
(2 \times 200)\end{array}$ \\
\hline
\end{tabular}

Table 2 shows that the ability of the follicle to respond to $P G F_{2 \alpha}$ is already acquired after 6 days of incubation and decreases by 8 days. On the other hand, fertilizability is close to zero after $6+1$ days of incubation and appears quite normal compared to in vivo-ovulated oocytes after incubation for $7+1$ days (table 3 ).

The relationship between optimal dose of $17 \alpha-20 \beta P$ for successful maturation (GVBD) and optimal dose for subsequent successful ovulation using PGF $_{2 \alpha}$ has been investigated in 2 females (fig. 2). In female 1, the Median efficient dose (MED) of $17 \alpha-20 \beta P$ to prepare for ovulation is around 10 times higher than the MED for maturation alone $\left(\simeq 380 \cdot 10^{-9} \mathrm{M}\right.$ against $\left.\simeq 30.10^{-9} \mathrm{M}\right)$, and around 30 times higher in female 2 . 
TABLE 3

Mean p. 100 of embryonic development in eggs fertilized after in vitro maturation from stage $1^{\circ}$, and $\mathrm{PGF}_{2}$-induced ovulation.

The number of inseminated eggs from 3 different females is shown in brackets

\begin{tabular}{lcc}
\hline $\begin{array}{c}\text { Maturation } \\
\text { treatment }\end{array}$ & $\begin{array}{c}\text { Duration of incubation prior } \\
\text { to addition of } \mathrm{PGF}_{2 \alpha} \text { (days) }\end{array}$ \\
\cline { 2 - 3 } & 6 & 7 \\
\hline TPE $\ldots \ldots \ldots \ldots$ & No assay & $86,4(132)$ \\
\hline $17 \alpha-\mathrm{GHH} \ldots \ldots \ldots$ & $0(28)$ & $89,8(127)$ \\
\hline
\end{tabular}

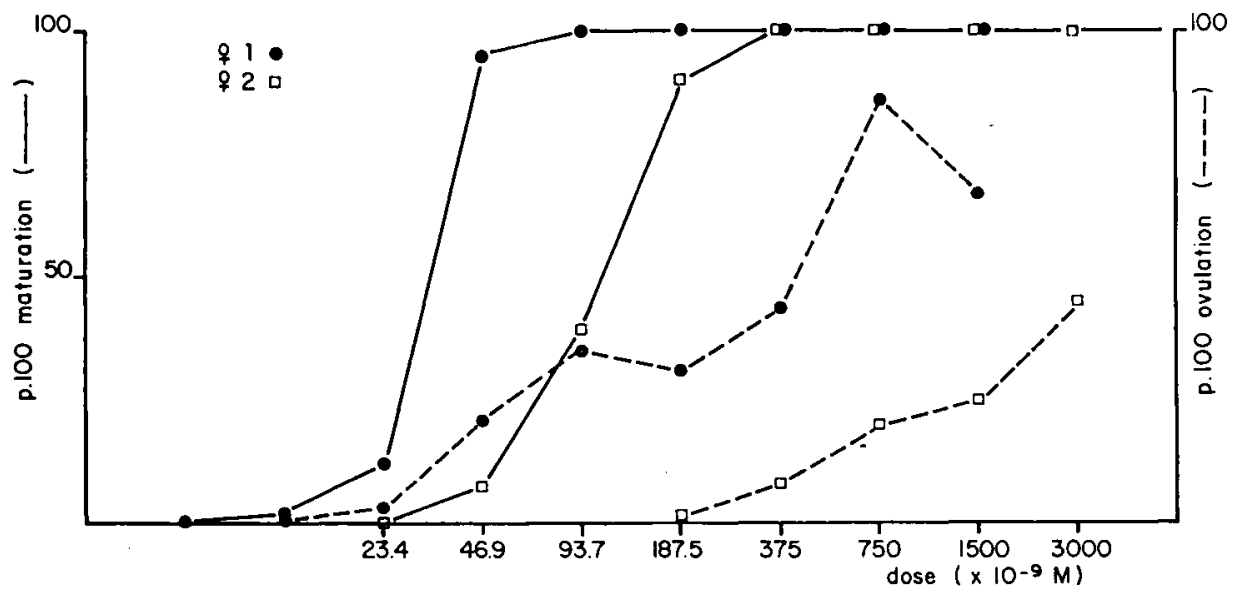

FIG. 2. - Relationship between dose of $17 \alpha-20 \beta P$ (continuous exposure in vitro from stage $1^{\circ}$ ), $P .100$ of oocyle maturation after 7-day incubation and $\mathrm{P} .100$ of ovulation 24 hrs ofter $P G F_{2} \alpha$ addition in two different females. Each value was obtained on 75 follicles.

\section{TABLE 4}

p. 100 ovulation induced by $\mathrm{PGF}_{2 \alpha}$ ofter 7 -day incubation from stage $1^{\circ}$ as a function of exposure time to $17 \alpha-20 \beta P$ at the beginning of incubation

(around 200 follicles per treatment and per female. Follicles are from 3 different females)

\begin{tabular}{|c|c|c|c|}
\hline \multirow{2}{*}{$\begin{array}{l}\text { Duration of exposure } \\
\text { to } 17 \alpha-20 \beta P\end{array}$} & \multicolumn{3}{|c|}{ Female Nr. } \\
\hline & 38 & 43 & 47 \\
\hline 4 hrs $\ldots \ldots \ldots \ldots \ldots$ & 57,6 & 54,8 & 51,5 \\
\hline 24 hrs ........... & 65,7 & 91,8 & 80,1 \\
\hline Permanent $\ldots \ldots \ldots$ & 55,2 & 68,9 & 61,4 \\
\hline
\end{tabular}


At the beginning of incubation, follicles were exposed to $17 \alpha-20 \beta P$ for different durations; ovulation response is shown in table 4 . The ovulation rate after 7-day incubation is significantly higher when follicles were exposed to $17 \alpha-20 \beta \mathrm{P}$ for $24 \mathrm{hrs}$ rather than 4 hours only or continuously.

When follicles were incubated from stage $1+$ after in vivo induction of maturation (fig. 1, table 5), some of the controls without hormone were able to ovulate after $\mathrm{PGF}_{2 \alpha}$, but $+\mathrm{G}+\mathrm{H}$ or $17 \propto 20 \beta \mathrm{P}$ treatment during incubation greatly enhances ovulation response to $\mathrm{PGF}_{2 \alpha}$.

\section{TABLE 5}

p. 100 ovulation following addition of $\mathrm{PGF}_{2 x}$ ofter 5 days incubation of follicles faken in vivo with oocytes at stage $1+$ and incubated with or without hormones

(all control and experimental oocytes from this stage reach GVBD without any hormone addition). Each value is obtained on 200 follicles

\begin{tabular}{|c|c|c|c|c|}
\hline \multirow{2}{*}{$\begin{array}{l}\text { Treatment during } \\
\text { maturation } \\
\text { (5 days) }\end{array}$} & \multirow{2}{*}{$\begin{array}{l}\text { Ovulation } \\
\text { treatment } \\
\text { (1 day) }\end{array}$} & \multicolumn{3}{|c|}{ Female } \\
\hline & & $\mathrm{Nr} 33$ & $\mathrm{Nr} 34$ & Nr 48 \\
\hline \multirow{2}{*}{ Control } & Control .. & 0 & 0 & 0 \\
\hline & $\mathrm{PGF}_{2 \alpha} \ldots$ & 25 & 28 & 4 \\
\hline \multirow{2}{*}{$t-G t H$} & Control .. & 0 & 0 & 0 \\
\hline & $\mathrm{PGF}_{2 \alpha} \ldots$ & $72 * *$ & $38 *$ & $82 * *$ \\
\hline \multirow{2}{*}{$17 \alpha-20 \beta P$} & Control .. & 0 & 0 & 0 \\
\hline & $\mathrm{PGF}_{2 \alpha}$ & $78 * *$ & $42 * *$ & $95 * *$ \\
\hline
\end{tabular}

TABLE 6

p. 100 ovulation following addition of $\mathrm{PGF}_{2 \alpha}$ after 4 days incubation of follicles taken in vivo with oocytes at stage 2 and incubated with or without hormones.

Each value is obtained on 200 follicles

\begin{tabular}{|c|c|c|c|c|}
\hline \multirow{2}{*}{$\begin{array}{l}\text { Treatment during } \\
\text { maturation } \\
\text { ( } 4 \text { days) }\end{array}$} & \multirow{2}{*}{$\begin{array}{c}\text { Orulation } \\
\text { treatment } \\
\text { (1 day) }\end{array}$} & \multicolumn{3}{|c|}{ Female } \\
\hline & & $\mathrm{Nr} 48$ & $\mathrm{Nr} 44$ & Nr 39 \\
\hline \multirow{2}{*}{ Control } & Control .. & 0 & 0 & 0 \\
\hline & $\mathrm{PGF}_{2 \alpha} \ldots$ & 45 & 2,2 & 25 \\
\hline \multirow{2}{*}{$t-G+H$} & Control .. & 10 & 0 & No assay \\
\hline & $\mathrm{PGF}_{2 \alpha}$ & 55 & $56 * *$ & No assay \\
\hline \multirow{2}{*}{$17 \alpha-20 \beta P$} & Control .. & 6 & 3,5 & 3 \\
\hline & $\operatorname{PGF}_{2 \alpha} \ldots$ & $70 * *$ & $43 * *$ & $45 * *$ \\
\hline
\end{tabular}


When incubation started from stage 2 (fig. 1, table 6), the same favorable effect of $t-G+H$ or $17 \alpha-20 \beta P$ upon ovulation preparation is seen. Moreover, following these treatments, some spontaneous ovulations occurred even without $\mathrm{PGF}_{2 \alpha}$ addition.

Finally, when incubation was started with stage 3 follicles after in vivo GVBD (fig. 1, table 7), ovulation rate after $\mathrm{PGF}_{2 \alpha}$ was equally high in control or in hormonetreated follicles so that no additional hormonal action was required any more for ovulation preparation.

\section{TABLE 7}

\section{p. 100 ovulation following addition of $\mathrm{PGF}_{2 \alpha}$ after 4 days incubation of follicles taken in vivo with oocytes af stage 3 and incubated with or without hormones.}

Each value is obtained on 200 follicles

\begin{tabular}{|c|c|c|c|}
\hline \multirow{2}{*}{$\begin{array}{l}\text { Treatment during } \\
\text { incubation } \\
\text { ( } 3 \text { days) }\end{array}$} & \multirow{2}{*}{$\begin{array}{l}\text { Ovulation } \\
\text { treatment }\end{array}$} & \multicolumn{2}{|c|}{ Female } \\
\hline & & Nr 39 & $\mathrm{Nr} 45$ \\
\hline \multirow{2}{*}{ Control } & Control ... & 21 & 6 \\
\hline & $\mathrm{PGF}_{2 x} \ldots$ & 83 & 88 \\
\hline \multirow{2}{*}{$\mathrm{t}-\mathrm{GtH}$} & Control .. & No assay & 5 \\
\hline & $\mathrm{PGF}_{2 \alpha} \ldots$ & No assay & 86 \\
\hline \multirow{2}{*}{$17 \alpha-20 \beta P$} & Control .. & 19 & 4 \\
\hline & $\mathrm{PGF}_{2 \alpha} \ldots$ & 79 & 82 \\
\hline
\end{tabular}

\section{Discussion.}

The main point demonstrated here is that ferfile trout eggs can be produced from follicles induced to mature and to ovulate entirely in vitro by successive hormonal treatments. Thus, the maturation processes induced in vitro are necessarily very similar to normal processes in vivo. They can be triggered by a crude trout pituitary extract, by $\mathrm{t}-\mathrm{GtH}$ (a trout gonadotropin purified in trout oocyte maturation assay) or by $17 \alpha-20 \beta P$, known to be the most likely steroid mediator of oocyte maturation in trout (Jalabert, 1976) produced by folliclar envelopes in response to t-GtH stimulation.

The observation that success of embryonic development is much better when ovulation is induced after 7-day incubation rather than after only 6-day incubation shows that acquisition of developmental capacity occurred later than GVBD (3-4 days), as already shown by Iwamatsu (1965) in Medaka. However, the delay is much longer in trout due to the lower temperature. In trout, $P \mathrm{FF}_{2 \alpha}$ appears able to artificially induce ovulation before developmental capacity is acquired. On the other hand, the follicular envelopes seem to lose their ability to respond to $\mathrm{PGF}_{2 \alpha}$ stimulation after 8-day incubation, and fertilizability of those oocytes was not assayed.

Incubation started at different stages of in vivo maturation demonstrated that $t-G t H$ or $17 \alpha-20 \beta P$ action is required until stage 3 (after GVBD) to prepare for ovulation. This fact has two main implications regarding the mode of hormonal 
action during follicle maturation (both oocyte maturation and preparation of follicular envelopes for ovulation) :

1) $17 \alpha-20 \beta P$ action must be continuous or renewed until stage 3 . This assumption is in good agreement with the fact that a 24-hr exposure to $17 \alpha-20 \beta P$ is more efficient than a 4-hr exposure for stage 10 follicles, but it is in apparent contradiction with the fact that 24-hr exposure is more efficient than continuous exposure. A main criticism of our " continuous exposure experiment" is that $17 \alpha-20 \beta P$ was added to the incubation medium only once at the beginning of incubation, and was not renewed : $17 \alpha-20 \beta P$ might be metabolized by the follicle and eventually transformed into more or less inhibitory derivatives. This was shown to be the case for progesterone in Xenopus oocyte maturation (Ozon ef al., 1975). However, even a 24-hour optimum exposure is very different from the few minutes of exposure to the same dose of $17 \alpha-20 \beta P$ required for subsequent successful GVBD in oocytes (Jalabert, 1976). Thus, the mode of $17 \alpha-20 \beta P$ action in preparing the follicle for ovulation, supposedly by stimulation of enzymatic processes promoting detachment between oocyte and granulosa cells (Jalabert and Szöllösi, 1975 ; Jalabert, 1976), is probably completely different from oocyte maturation induction. On the other hand, the doses of $17 \alpha-20 \beta P$ required for ovulation preparation are much higher than those for oocyte maturation, which might imply a non-specific action in preparation for ovulation. However, recently Campbell et al. (in preparation) have identified $17 \alpha-20 \beta P$ in trout plasma during maturation at concentrations of the same order of magnitude.

2) $\mathrm{t}-\mathrm{GtH}$ action must also be continuous or renewed as it exhibits the same positive action as $17 \alpha-20 \beta P$ on ovulation success of follicles taken after in vivoinduced maturation. This induction is supposed to be triggered first by a rise in $t-G+H$ secretion. However, from our experiments, it seems obvious that the follicular tissue does not then acquire an inertia for the secretion of the necessary amount of $17 \alpha-$ $20 \beta P$ required for ovulation, but needs persistant stimulation by high levels of $\mathrm{t}-\mathrm{G} \mathrm{HH}$. This is in good agreement with in vivo observations by Jalabert ef al. (1976) showing a progressive rise in mean level of plasma $\mathrm{t}-\mathrm{G}+\mathrm{H}$ during in vivo natural maturation from stage 1 to stages 2 and 3 .

The main contradiction between our data and those of Sakun and GureevaPreobrazhenskaya (1975) remains. Despite the lack of exact information concerning the yield of spontaneous ovulations observed in vitro by those authors, such spontaneous ovulations after incubation from stage 1 rarely occurred in our incubation conditions, and $\mathrm{PGF}_{2 \alpha}$ action was always necessary to induce a significant number of ovulations after maturation. Moreover, follicles taken in vivo at stage 3 a short time before normal ovulation do not ovulate in vitro in the absence of PGF $_{2 \alpha}$ or Epinephrine stimulation (Jalabert and Szöllösi, 1975 ; Jalabert, 1976), even when treated with high levels of pituitary extracts. The difference in the nature of the incubation medium is probably not a good explanation, as Goetz (1976) using the same medium as Sakun ef al. (Cortland's solution) did not observe spontaneous ovulation after complete in vitro maturation of brook trout follicles. Some other differences in methodology could be responsible for the different ovulation results. Sakun et al. used heavy doses of progesterone, 50 times higher than our routine dose of $17 \alpha-20 \beta P$, and pink salmon pituitary extract; they renewed the incubation medium after $48 \mathrm{hrs}$. This could have eliminated any inhibitory metabolism products. 
Two hypotheses thus remain; one is that trout pituitary extract, $t-G+H$ and $17 \alpha-20 \beta P$, although specific for induction of normal oocyte maturation, are nonspecific sources for induction of subsequent ovulation and thus need to be assisted by extra-physiological PGF $2 \alpha$. The other hypothesis is that our methodology dissociates and reveals some physiological features like $\mathrm{PGF}_{2 \alpha}$ involvement in trout ovulation, involvement which has also been hypothesized in goldfish ovulation by different methods (Stacey and Pandey, 1975).

$27^{e}$ Congrès international des Sciences physiologiques, Symposium « Germ and somatic cell interoction 》 Paris, 21-23 juillet 1977.

Acknowledgments. - I wish to thank Dr. John R. Pike of the Upjohn Co., Kalamazoo, Michigan who donated the prostaglandin used in these experiments. My colleagues, B. Breton and A. Fostier prepared the pure trout gonadotropin $\mathrm{t}-\mathrm{GtH}$ and the pure $17 \alpha-20 \beta P$, respectively, which were used in this work. I am indebted to Mrs. Alice Daifuku for improving the English and typing the manuscript, and to Miss Rose-France Masson for drawing the figures.

Résumé. Des follicules ovariens de Truite arc-en-ciel présentant des ovocyłes au stade de la vésicule germinative périphérique (fig. 1 , stade $1^{\circ}$ avant induction naturelle de la maturation) ont été incubés à $10^{\circ} \mathrm{C}$ en présence d'hormones destinées à induire la maturation. L'ovulation a été induite par PGF $2 \alpha$ ajoutée au milieu pendant $24 \mathrm{~h}$, après 6,7 et 8 jours d'incubation. Dans ces conditions, l'extrait hypophysaire de Truite, la gonadotropine pure t-GtH ou la $17 \alpha$ hydroxy-20 $\beta$ dihydroprogestérone $(17 \alpha-20 \beta \mathrm{P})$ se sont révélées aptes à produire des ovocytes fécondables après $7+1$ jours d'incubation. Après seulement 6 jours d'incubation, l'ovulation en réponse à l'action de PGF $2 \alpha$ est déjà possible, mais la fécondabilité est quasi nulle. Après 8 jours, la sensibilité à PGF $2 \alpha$ diminue (tabl. 1 , $2,3)$. La dose de $17 \alpha-20 \beta P$ nécessaire à l'ovulation ultérieure sous l'action de PGF $2 \alpha$ est plus de 10 fois supérieure à celle qui serait nécessaire à la seule maturation ovocytaire (fig. 2). Une exposition de $24 \mathrm{~h}$ en début d'incubation à l'action de la $17 \alpha-20 \beta \mathrm{P}$ est plus efficace qu'une exposition de $4 \mathrm{~h}$ ou continue (tabl. 4).

Lorsque des follicules sont placés en incubation alors que la maturation ovocytaire est déjà engagée in vivo (à n'importe quel moment depuis le stade $1+$ jusqu'à l'éclatement de la vésicule germinative ; voir fig. 1), l'action de t-GtH ou de la $17 \alpha-20 \beta P$ augmente le pourcentage d'ovulations induites par PGF $2 \alpha$.

Ces faits démontrent que la $17 \alpha-20 \beta$ P qui est le médiateur le plus vraisemblable de la maturation ovocytaire chez la Truite peut aussi induire la préparation du follicule à l'ovulation ; celle-ci requiert cependant des doses et des temps d'action supérieurs à ceux strictement nécessaires à l'induction de la maturation ovocytaire, ce qui implique aussi que l'action de $\mathrm{t}-\mathrm{G}+\mathrm{H}$ in vivo doit s'effectuer à un niveau et avec une durée supérieurs.

La fécondation des œufs produits dans ces conditions démontre que les processus de maturation et d'ovulation contrôlés in vitro doivent être très voisins des processus naturels.

\section{References}

BILLARD R., PETIT J., JALABERT B., SZOLLOOSI D., 1974. Artificial insemination in trout using a sperm Diluant. Symp. on the Early Life History of Fish, OBAN, Blaxter Ed., 715-723.

BRETON B., JALABERT B., REINAUD P., 1976. Purification of gonadotropin from rainbow trout (Salmo gairdnerii Richardson) pituitary glands. Ann. Biol. anim. Bioch. Biophys., 16, 25-36. 
FOSTIER A., JALABERT B., TERQUI M., 1973. Action prédominante d'un dérivé hydroxylé de la progestérone sur la maturation in vitra des ovocytes de la truite arc-en-ciel Salmo gairdnerii. C. R. Acad. Sci. Paris, Sér. D, 277, 421-424.

GOETZ F. W. Jr., 1976. The in vitro induction of final maturation and ovulation in brook trout (Salvelinus fontinalis) and yellowperch (Perca flavescens) ova and the hormonal control of final maturation in ova of other fish species. PhD. Thesis. Univ. of Wyoming, La Ramie, Wyoming.

IWAMATSU T., 1965. On fertilizability of pre-ovulation eggs in the Medaka, Oryzias latipes. Embryologia, 8, 327-336.

IWAMATSU T., 1967. On acquisition of developmental capacity in oocytes of the Medaka Oryzias latipes. Ann. Zool. Jap., 40, 6-19.

JALABERT B., 1976. In vitro oocyte maturation and ovulation in rainbow trout (Salmo gairdnerii), northern pike (Esox lucius), and goldfish (carassius aurolus). J. Fish. Res. Bd. Can., 33, 974-988.

JALABERT B., BRETON B., BILLARD R., 1974. Dosage biologique des hormones gonadotropes de poissons par le test de maturation in vitro des ovocytes de truite. Ann. Biol. anim. Bioch. Biophys., $14,217-228$.

JALABERT B., BRETON B., BRZUSKA E., FOSTIER A., WIENIAWSKI J., 1977. A new tool for induced spawning : the use of $17 \alpha$-hydroxy-203-dihydroprogesterone to spawn carp at low temperature. Aquaculture, 10, 353-364.

JALABERT B., BRETON B., BRY C., 1972. Maturation ef ovulation in vitro des ovocytes de la truite arc-en-ciel Salmo gairdnerii. C. R. Acad. Sci. Paris, Sér. D, 275, 1139-1142.

JALABERT B., BRY C., BRETON B., CAMPBELL C., 1976. Action de la $17 \alpha$-hydroxy-20 $\beta$ dihydroprogestérone et de la progestérone sur la maturation et l'ovulation in vitro et sur le niveau d'hormone gonadotrope plasmatique t-GtH chez la truite Arc-en-ciel Solmo gairdnerii. C. R. Acad. Sci. Paris, Sér. D, 283, 1205-1208.

JALABERT B., BRY C., SZÖLLÖSI D., FOSTIER A., 1973. Ełude comparée de l'action des hormones hypophysaires et stéroïdes sur la maturation in vitro des ovocytes de la truite et du carassin (Poissons téléostéens). Ann. Biol. anim. Bioch. Biophys., 13 (hors série), 59-72.

JALABERT B., SZÖLLÖSI D., 1975 . In vitro ovulation of trout oocytes : effect of prostaglandins on smooth muscle-like cells of the theca. Prostaglandins, 9, 765-778.

OZON R., BELLE R., SERRES C., FOUCHET C., 1975. Mechanism of action of progesterone on amphibian oocytes. A possible biological role for progesterone metabolism. Mol. cellul. Endocr., 3,, 221-231.

SAKUN O. F., GUREEVA-PREOBRAZHENSKAYA E. V., 1975. On the problem of maturation of teleostei oocytes in vitro. Vest. Leningr. Univ., 15, 15-22.

STACEY N. E., PANDEY S., 1975. Effects of indomethacin and prostaglandins on ovulation of goldfish. Prosfaglandins, 9, 597-608. 